\title{
Conduction Block in PMP22 Deficiency
}

\author{
Yunhong Bai, ${ }^{1}$ Xuebao Zhang, ${ }^{1}$ Istvan Katona, ${ }^{1}$ Mario Andre Saporta, ${ }^{1}$ Michael E. Shy, ${ }^{1}$ Heather A. 0’Malley, ${ }^{3}$ \\ Lori L. Isom, ${ }^{3}$ Ueli Suter, ${ }^{4}$ and Jun $\mathrm{Li}^{1,2}$ \\ ${ }^{1}$ Department of Neurology, Wayne State University, and ${ }^{2}$ John D. Dingell VA Medical Center, Detroit, Michigan 48201, ${ }^{3}$ Department of Pharmacology and \\ Program in Cellular and Molecular Biology, University of Michigan, Ann Arbor, Michigan 48109, and 4Department of Biology, Institute of Cell Biology, \\ Eidgenössische Technische Hochschule Zürich, 8093 Zurich, Switzerland
}

Patients with PMP22 deficiency present with focal sensory and motor deficits when peripheral nerves are stressed by mechanical force. It has been hypothesized that these focal deficits are due to mechanically induced conduction block (CB). To test this hypothesis, we induced $60-70 \%$ CB (defined by electrophysiological criteria) by nerve compression in an authentic mouse model of hereditary neuropathy with liability to pressure palsies (HNPP) with an inactivation of one of the two $p m p 22$ alleles $\left(p m p 22^{+/-}\right)$. Induction time for the $\mathrm{CB}$ was significantly shorter in $p m p 22^{+/-}$mice than that in $p m p 22^{+/+}$mice. This shortened induction was also found in myelin-associated glycoprotein knock-out mice, but not in the mice with deficiency of myelin protein zero, a major structural protein of compact myelin. Pmp22 $2^{+-}$nerves showed intact tomacula with no segmental demyelination in both noncompressed and compressed conditions, normal molecular architecture, and normal concentration of voltage-gated sodium channels by [ $\left.{ }^{3} \mathrm{H}\right]$-saxitoxin binding assay. However, focal constrictions were observed in the axonal segments enclosed by tomacula, a pathological hallmark of HNPP. The constricted axons increase axial resistance to action potential propagation, which may hasten the induction of CB in Pmp22 deficiency. Together, these results demonstrate that a function of Pmp22 is to protect the nerve from mechanical injury.

\section{Introduction}

Peripheral myelin protein-22 (PMP22) is primarily expressed in the compact myelin of peripheral nerves and is encoded by the PMP22 gene within the DNA segment of human chromosome 17p11.2 (Jetten and Suter, 2000). This gene is important clinically. Overexpression of PMP22 causes Charcot-Marie-Tooth disease type 1A (CMT1A), the most common heritable neuropathy afflicting $\sim 1: 5000$ people of all ethnic backgrounds. Alternatively, haploinsufficiency of PMP22 results in a different disorder, hereditary neuropathy with liability to pressure palsies (HNPP) (Chance et al., 1993; Li et al., 2007). Pathologically, CMT1A is characterized by dysmyelination/demyelination with frequent onion bulb formation (Dyck and Lambert, 1968; Robertson et al., 2002), whereas HNPP is characterized by the presence of frequent focal myelin folds known as tomacula (Madrid and Bradley, 1975; Yoshikawa and Dyck, 1991).

HNPP is characterized by focal episodes of weakness and sensory loss (Madrid and Bradley, 1975; Marazzi et al., 1988; Li et al., 2004). These focal deficits are usually triggered by physical activ-

Received Aug. 29, 2009; revised 0ct. 21, 2009; accepted Nov. 13, 2009.

This research is supported by grants from the National Institute of Neurological Disorders and Stroke (K08 NS048204 to J.L.), the Muscular Dystrophy Association (MDA 4029 to J.L.), the Veterans Administration (B6243R to J.L.), the Swiss National Science Foundation and the National (enter of Competence and Research Neural Plasticity and Repair (to U.S.), the National Multiple Sclerosis Society (RG2882 and RG3771A4/3 to L.L.I.), the University of Michigan Training Program in Cellular and Molecular Biology (National Institutes of Health General Medicine GM007315-31 to H.0.), and University of Michigan Rackham Predoctoral Fellowship to H.O. We thank Ms. Yanmei Yuan for her technical assistance.

Correspondence should be addressed to Dr. Jun Li at his present address: Department of Neurology, Vanderbilt University School of Medicine, AA0204F Medical Center North, 1161 21st Avenue South, Nashville, TN 37232. E-mail: jun.li.2@vanderbilt.edu.

D0I:10.1523/JNEUROSCI.4264-09.2010

Copyright $\odot 2010$ the authors $\quad 0270-6474 / 10 / 300600-09 \$ 15.00 / 0$ ities, including stretching, repetitive motions of the affected limb, or compression ( $\mathrm{Li}$ et al., 2004), suggesting that there is nerve vulnerability to mechanical force in PMP22 deficiency. Whether this is the case remains to be demonstrated and is an important issue that is not only clinically relevant but essential for understanding the biological function of PMP22, since HNPP is a "loss-of-function" model.

PMP22 has been suggested to play a role in proliferation, differentiation, and death of Schwann cells (Jetten and Suter, 2000; Sancho et al., 2001; Amici et al., 2007). These functions can be further evaluated in null models such as homozygous pmp22deficient ( $p m p 22^{-1-}$ ) mice (Sancho et al., 2001; Amici et al., 2007). However, it is unlikely that any of these three functions play a role in HNPP, a heterozygous disorder, since $p m p 22^{+/-}$mice, an authentic model of the human disease, have normal Schwann cell numbers and compact myelin (Adlkofer et al., 1997).

It has been hypothesized that the transient focal deficits in HNPP are caused by reversible conduction block (CB) (Lewis et al., 2000; Li et al., 2002, 2004), a failed propagation of the action potential along myelinated nerve fibers (Cornblath et al., 1991; Kaji, 2003). To investigate this possibility and the role of PMP22 in nerve resistance to mechanical stress, we have created a $\mathrm{CB}$ model in $p m p 22^{+/-}$mice by nerve compression. Our results demonstrated that CB can be mechanically induced in $p m p 22^{+1-}$ nerves more rapidly than in normal nerves.

\section{Materials and Methods}

Pmp22-deficient mice, genotyping, and cross-breeding

The $p m p 22^{+/-}$mouse was generated by using homologous recombination technique to inactivate the pmp22 gene (Adlkofer et al., 1995). Peripheral nerves from this mouse showed typical pathological changes of HNPP, including tomacula (Adlkofer et al., 1995, 1997). 
Due to cytomegalovirus infection, this mouse had to be rederived embryonically to eliminate the viruses (assisted by Van Andel Rearch Institute, Grand Rapids, MI). The rederived mouse showed clinical phenotype and pathological changes identical to the mouse from original colony.

A breeding colony is maintained in Wayne State University animal facility. The Animal Investigational Committee in the institution has approved the use of animals for this study. For genotyping, DNA was isolated from clipped mouse tails and subjected to PCR analysis. Genotypes were determined as described in previous publications (Adlkofer et al., 1995, 1997). For the control mice with heterozygous deletion of myelin protein zero $(M P Z)$ and homozygous knock-out of myelinassociated glycoprotein ( $\mathrm{mag}$ ), procedures for breeding and genotyping have been described in previous publications (Shy et al., 1997; Yin et al., 1998).

To study axonal constriction, we have cross-bred $p m p 22^{+/-}$mouse with YFP transgenic mouse $\left(\right.$ YFPtg $\left.^{+/+}\right)$. The YFPtg mouse was transferred from Dr. Derron Bishop's laboratory (Indiana University School of Medicine, Muncie, IN) and carries a transgene expressing yellow fluorescent protein (YFP) specifically in neurons under the drive of Thy-1 promotor (Bishop et al., 2004). This gives clear and intense labeling of all axons.

\section{Nerve conduction study}

Mice were anesthetized with Avertin $(250 \mathrm{mg} / \mathrm{kg})$. Body temperature was allowed to equilibrate at room temperature. One pair of stimulating electrodes was positioned percutaneously at the sciatic notch. A second pair was inserted adjacent to the tibial nerve at the ankle. Compound muscle action potential (CMAP) was recorded from the intrinsic foot muscle using needle electrodes. CMAP amplitudes were measured from baseline to the peak of negative deflection. The ratio between CMAP amplitude from proximal (P) and distal (D) stimulation (P/D ratio) was calculated. This minimized the effect of changes in the absolute amplitude values due to variation in the electrode placement during different recordings in the same animals.

\section{Induction of $C B$ by compression}

All mice in compression experiments were 2-3 months old. Anesthetized mice were placed on a Styrofoam board. Nerve conduction study (NCS) was done as described above. CMAP was recorded before compression. $\mathrm{CB}$ was induced at tibial and sciatic nerves by two different techniques as described below.

$C B$ at the tibial nerve. Mice were placed in prone position. The right leg rested on a metal plate with a width of $1 \mathrm{~cm}$. Compression was delivered by a loop of nylon cord of $1 \mathrm{~mm}$ width with different weights attached (200-1000 g). The cord ran cross the dorsal side of the leg $3 \mathrm{~mm}$ above the ankle to compress the tibial nerve (Fig. $1 A-C$ ). Conduction velocities and $\mathrm{P} / \mathrm{D}$ ratios were obtained every $15 \mathrm{~min}$ after the compression started. Toward the onset of $\mathrm{CB}$, changes in conductions became accelerated. Thus, measurements were performed more frequently (every $5 \mathrm{~min}$ ) until the ratio was reduced to 0.4 to $0.3(60-70 \% \mathrm{CB})$. It has not been possible to make $\mathrm{CB}$ exactly at 60 or $70 \%$; thus, all CBs were targeted between 60 and $70 \%$.

$C B$ at the sciatic nerve. An incision was made around the sciatic notch to expose the sciatic nerve. The nerve was wrapped with two layers of gauze that was soaked with saline. Compression was applied on the surface of gauze with a $20 \mathrm{~g} / \mathrm{mm}^{2}$ vessel clamp (clamp width $=1.5 \mathrm{~mm}$; catalog number Tks-1-20 g; Aros Surgical Instruments). Conduction velocity and $\mathrm{P} / \mathrm{D}$ ratios were collected as described above.

\section{Semithin section and EM}

These techniques were described in our previous studies (Li et al., 2005; Zhang et al., 2008). In brief, mice were transcardially perfused with $4 \%$ paraformaldehyde and 3.5\% glutaraldehyde. Sciatic or tibial nerves were dissected and postfixed for $24 \mathrm{~h}$. Nerves were then osmicated for $1.5 \mathrm{~h}$, dehydrated, and embedded in Epon. Tissue blocks were sectioned with 1 $\mu \mathrm{m}$ thickness and stained with methylene blue for light microscopic examination. The blocks were then trimmed and sectioned into ultrathin sections for EM examination (Zeiss EM 900).
For osmicated teased nerve fiber studies, nerves were dissected and fixed as described above, followed by dehydration and osmication in $1 \%$ osmium tetroxide before embedding in Epon. The nerve bundles were teased in fluid Epon under the dissection microscope by using fine forceps. The glass slides with teased nerve fibers were hardened in the $60^{\circ} \mathrm{C}$ oven, mounted with coverslip, and examined under the light microscope.

\section{Teased nerve fiber immunohistochemistry}

This technique has been described in our previous studies (Bai et al., 2006; Zhang et al., 2008). In brief, nerves were fixed in $4 \%$ paraformaldehyde for $30 \mathrm{~min}$ to $16 \mathrm{~h}$ (depending on which primary antibodies were to be used). Sciatic nerves were teased into individual fibers on glass slides. The slides were dried overnight, reacted with primary antibodies, stored at $4^{\circ} \mathrm{C}$ overnight, and then incubated for $1.5 \mathrm{~h}$ with secondary antibodies. The stained slides were examined under a Leica fluorescent or a Nikon confocal microscope. All antibodies used are listed in Table 1.

\section{$\left[{ }^{3} \mathrm{H}\right]$-saxitoxin binding assay}

Peripheral nerves, including bilateral sciatic, tibial, peroneal, roots, and brachial plexus, were dissected from each mouse. Membrane protein extracts were prepared as previously described (Catterall et al., 1979). $\left[{ }^{3} \mathrm{H}\right]$-saxitoxin $\left(\left[{ }^{3} \mathrm{H}\right]-\mathrm{STX}\right)$ binding was performed as described previously, using rat brain membranes as a positive control (Isom et al., 1995; Chen et al., 2002). Briefly, membrane extracts were washed in binding buffer [containing the following (in mM): 50 HEPES-Tris, pH 7.5, 130 choline chloride, $5.4 \mathrm{KCL}, 0.8 \mathrm{MgSO}_{4} 5.5$ dextrose]. Membranes were then pelleted by centrifugation at $4^{\circ} \mathrm{C}$ and resuspended in ice-cold binding buffer. Two hundred microliters of each sample was aliquoted into polypropylene tubes on ice (in triplicate), containing $25 \mu \mathrm{l}$ of a $50 \mathrm{nM}$ $\left[{ }^{3} \mathrm{H}\right]$-STX stock ( $5 \mathrm{~nm}$ final concentration in the assay), plus $25 \mu \mathrm{l}$ of 100 $\mu \mathrm{M}$ unlabeled tetrodotoxin stock ( $10 \mu \mathrm{M}$ final) or binding buffer to assess nonspecific binding. All samples were incubated on ice in a $4^{\circ} \mathrm{C}$ cold room for $1 \mathrm{~h}$. Binding was terminated by rapid vacuum filtration over Whatman GF/C filters that have been presoaked in wash buffer [containing the following (in mM): 163 choline chloride, 5 HEPES-Tris, $\mathrm{pH} 7.5$, $1.8 \mathrm{CaCl}, 0.8 \mathrm{MgSO}_{4}$ ) containing $1 \mathrm{mg} / \mathrm{ml} \mathrm{BSA}$, followed by three rapid washes with ice-cold wash buffer. $\left[{ }^{3} \mathrm{H}\right]-\mathrm{STX}$ bound to the filters was assessed by scintillation counting. Specific binding is assessed by subtraction of nonspecific binding in the presence of tetrodotoxin. Specific ${ }^{3} \mathrm{H}$ activity was normalized to protein concentration and finally expressed as femtomoles of sodium channels per milligram of protein, based on the established 1:1 stoichiometry of STX binding to neuronal sodium channels. For each experiment, two samples were collected from 11 to 15 pmp $22^{+/+}$mice and from 11 to 15 pmp $22^{+/-}$mice.

\section{Results \\ CB mechanically was induced more rapidly in $p m p 22^{+/-}$ nerves, but not in MPZ-deficient nerves}

To generate a model of $\mathrm{CB}$ in mice we performed a series of compressions on the tibial nerve using a nylon cord attached to different weights $(200-1000$ g) (Fig. $1 A-C)$. We identified an ideal weight of $400 \mathrm{~g}$ that induces CB within $1.5 \mathrm{~h}$. The $400 \mathrm{~g}$ weight was then used for the remaining experiments. Before compression, amplitudes of CMAP from proximal and distal stimulations were similar (Fig. 1D). Within 4-5 min of compression, CMAP amplitude from proximal stimulation began to decrease and continued to drop if the compression was not removed. Once the $\mathrm{P} / \mathrm{D}$ ratio reached $0.4-0.3$, a $60-70 \% \mathrm{CB}$ was diagnosed and the compression was removed (Fig. 1D). There was a progressive prolongation of latencies with proximal stimulation before the $\mathrm{CB}$ while the distal motor latency remained unchanged, suggesting that there was focal slowing of conduction across the site of compression. Once $60-70 \%$ CB was achieved, the mice were returned to their cage. On waking from anesthesia $(<1 \mathrm{~h})$, the mice dragged their compressed leg for $\sim 12 \mathrm{~h}$. The compression system used in our experiments was chosen to deliver a mild force and minimize the possibility of axonal transection. 
To examine susceptibility to compression in Pmp22-deficient nerves, we performed the compression experiments in 19 pmp $22^{+/-}$and 21 pmp $22^{+/+}$mice. The average time to induce $\mathrm{CB}$ in the pmp $22^{+/-}$mice was $35 \pm 13 \mathrm{~min}$, which was significantly shorter than with wildtype mice ( $55 \pm 38$ min; $p<0.01$ ).

Tibial nerves are located on the medial side of the ankle in mice as well as humans. To determine whether different contact angles between nylon cord and the vertical line of the mouse leg were affecting our results, we performed another set of compression experiments in which we altered the angle by 15 degrees (Fig. $1 C$, arrow). Similar results were observed. The mean duration for inducing CB between the pmp $22^{+1-}$ mice $(n=17)$ and wildtype $(n=17)$ was $31.3 \pm 9.5$ and $56.8 \pm$ $14.8 \mathrm{~min}$, which were again significantly different $(p<0.01)$.

Tibial nerves are cushioned by skin and subcutaneous tissues, which may vary from one mouse to another. In addition, the anatomical position of tibial nerves on the medial side of the ankle may also vary from mouse to mouse. To eliminate these potential factors, we surgically exposed sciatic nerves in the mice and compressed them directly using a vessel clamp (see technical details in Method section). Once again, the mean of duration for CB induction was shorter in $p m p 22^{+/-}$mice than that in $p m p 22^{+/+}$mice $(17.0 \pm 4.4 \mathrm{vs}$ $29.1 \pm 5.8 \mathrm{~min} ; n=7$ mice for each genotype; $p<0.001)$.

To ensure that the shortened induction of $\mathrm{CB}$ is not due to the reduced CMAP amplitudes in $p m p 22^{+/-}$mice, we reanalyzed our data from both sets of experiments using nylon cord compression (32 pmp $22^{+/-}$or 35 pmp $22^{+/+}$mice). Mice were separated into low and high CMAP groups. No significant difference between these groups was found in the onset of CB (supplemental Table 1, available at www.jneurosci.org as supplemental material $)(p>0.05)$.

To determine whether the shortened induction of CB is specific to the deficiency of Pmp22, we performed similar studies with heterozygous $m p z$ knock-out mice $\left(m p z^{+/-}\right)$. Like PMP22, MPZ is a major structural protein $(>50 \%$ of all PNS myelin proteins) specific to compact myelin in the PNS (Shy et al., 2001). Deficiency of MPZ would be expected to negatively affect myelin stability. Indeed, homozygous deletion of $m p z$ impairs myelin compaction (Martini et al., 1995), but abnormalities of myelin and axons occur even during embryonic stage and make the homozygotes unsuitable for control experiments. However, heterozygous null $m p z\left(m p z^{+/-}\right)$mice do not develop significant electrophysiological and pathological abnormalities until the age of 6-12 months (Shy et al., 1997). Thus, before the age of 6 months old, they are an excellent animal model for controls. The

$\mathbf{E}$
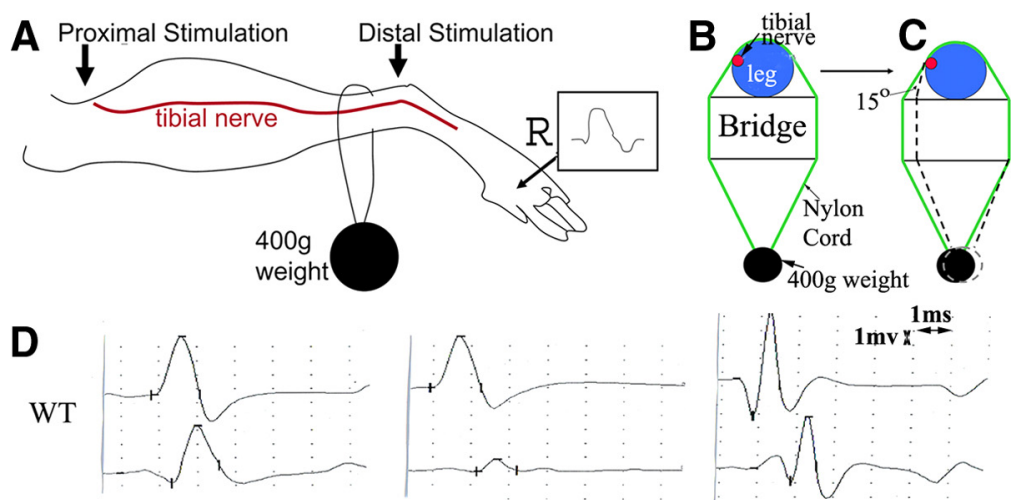
Compression

Recovery

Figure 1. Experimental paradigm for nerve compression and mechanically induced $C B$ in mice. $A$, This diagram shows the "bridge") with a width of $\sim 1 \mathrm{~cm}$. Tibial nerves usually run on the medial side of the ankle (red dot). $C$, In the second set of (n) the angle between the nylon cord and the vertical line of leg is reduced by 15 degrees by shortening the length of the

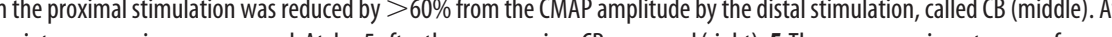
mouse. (B did not recover at day 5 following compression (right). Sensitivity $=1 \mathrm{mV}$; speed $=1 \mathrm{~ms}$. Notice that atency and conduction velocity. Nevertheless, this issue does not affect the measurement of CMAP amplitudes or any of ou short delay from 1 to 2 or from 3 to 4 ) across the elbow was identified within $1 \mathrm{~cm}$ segment of the nerve demonstrating the very focal nature of the slowing. (B was conspicuous in this case. The arrow indicates the third response, which had a $>50 \%$ amplitude drop of motor response and was associated with weakness in muscles innervated by the ulnar nerve.

induction time of $\mathrm{CB}$ on the vessel-clamp compressed sciatic nerves was not significantly different between the $m p z^{+/+}$and $m p z^{+/-}$mice $(25.3 \pm 5.6$ vs $25.3 \pm 6.9 \mathrm{~min} ; n=6$ mice for each genotypic group; $p>0.05$ ). In addition, teased nerve fiber studies on the sciatic nerves showed no segmental demyelination or tomacula in $m p z^{+/-}$mice. Together, these data demonstrate that a function of Pmp22 is to protect the nerve from mechanical injury, which is not necessarily related to myelin stability.

\section{CB mechanically induced more rapidly in $\mathrm{mag}^{+/-}$nerves}

Next, we performed the nerve compression in $\mathrm{mag}^{-1-}$ mice using the vessel clamp technique. We chose these animals because homozygous mag null mice also develop tomacula. Tomacula have been detected in nerves of these mice at 1 month of age and 
Table 1. Primary antibodies

\begin{tabular}{|c|c|c|c|c|c|}
\hline Antibody & Source and catalog number & Species raised in & Specific antigen & Type & Reference \\
\hline MAG & Zymed Laboratories 34-6200 & Rabbit & Shared C-terminal region of the small and large MAG & Polyclonal & Yamamoto et al., 1994 \\
\hline $\mathrm{K}_{\mathrm{v}} 1.2$ & Sigma P 8732 & Rabbit & GST fusion protein with aa 417-498 & Polyclonal & McKinnon, et al., 1989 \\
\hline Pan- $\mathrm{Na}_{v}$ & Sigma S 8809 & Mouse & Synthetic peptide CTEEQKKYYNAMKKLGSKK & Polyclonal lgG & Ulzheimer et al., 2004 \\
\hline Caspr & Dr. E. Pelles ${ }^{a}$ & Rabbit & Rat cytoplasmic domain & Polyclonal lgG & Einheber et al., 1997 \\
\hline MBP & Chemicon MAB 386 & Rat & aa $82-87$, bovine MBP & Monoclonal lgG & Li et al., 2005 \\
\hline
\end{tabular}

aa, Amino acids. ${ }^{a}$ Department of Molecular Cell Biology, The Weizmann Institute of Science, Rehovot, Israel.

Table 2. Recovery of CB in pmp22 ${ }^{+/-}$mice

\begin{tabular}{llllll}
\hline & No recovery & & & \multicolumn{2}{l}{ Recovery } \\
\cline { 2 - 3 } \cline { 5 - 6 } Genotype & $3 \mathrm{~d}$ & $5 \mathrm{~d}$ & & $3 \mathrm{~d}$ & $5 \mathrm{~d}$ \\
\hline Wild type & $2^{a} / 5^{b}(40 \%)$ & $1 / 7(14 \%)$ & & $3^{c} / 5^{d}\left(0 \mathrm{p}^{e}\right)$ & $6 / 7(1 \mathrm{p})$ \\
pmp22 & $4 / 4(100 \%)$ & $4 / 7(57 \%)$ & & $0 / 4(0 \mathrm{p})$ & $3 / 7(2 \mathrm{p})$ \\
\hline
\end{tabular}

${ }^{a}$ Animals with no recovery.

${ }^{b}$ Total animals in this group.

'Animals with recovery.

${ }^{d}$ Total animals in this group.

${ }^{e} 0 p$, No animals with partial recovery; $1 p$, one animal with partial recovery; $2 p$, two animals with partial recovery.

affect $50 \%$ of paranodes in 3-month-old $\mathrm{mag}^{-1-}$ mice (Yin et al., 1998). This prevalence of tomacula is comparable to that in 6-month-old $p m p 22^{+/-}$mice. Heterozygous mag-deficient mice $\left(\mathrm{mag}^{+/-}\right)$, unlike heterozygous $p m p 22^{+/-}$animals, have no tomacula and no pathological phenotype (Yin et al., 1998). We therefore performed the compression experiments in $\mathrm{mag}^{-1-}$ mice at 2 months of age. Surprisingly, teased nerve fiber examination showed no tomacula/axonal constrictions in $\mathrm{mag}^{-1-}$ nerves. Nevertheless, $\mathrm{CB}$ was induced more rapidly in $\mathrm{mag}^{-1-}$ mice than that in $\mathrm{mag}^{+/+}$animals $(9.0 \pm 2.5$ vs $20.9 \pm 9.4 \mathrm{~min} ; n=7$ mice for each genotypic group; $p<0.01)$. Since there were no tomacula in these homozygous Mag-deficient mice, this increased susceptibility to develop CB has to be caused by a different mechanism(s) than in the $p m p 22^{+/-}$mice. These findings suggest that vulnerability to mechanically induced $\mathrm{CB}$ in the peripheral nerves is not specific to Pmp22 deficiency, although the mechanisms for the CB may differ for different molecules.

\section{Recovery of CB delayed in Pmp22-deficient nerves}

NCS were repeated 3 or $5 \mathrm{~d}$ after the induction of CB in the first compression model, in which a nylon cord, attached to a weight, compressed the tibial nerve. CB completely recovered in 3 of 5 wild-type mice by the third day after compression and in 6 of the 7 wild-type mice by the fifth day (seventh with a partial recovery) (Table 2, Fig. $1 D$ ). In contrast, $\mathrm{CB}$ showed no complete recovery in any of 11 pmp $22^{+/-}$mice at day 3 or day 5 , and partial recovery in only half of the mice by day 5 (Table 2, Fig. $1 E)$. These findings suggest that deficiency of Pmp22 results in slowed recovery from CB in the PNS.

To evaluate the pathological changes in the compressed nerves, we next obtained semithin sections at transverse $2-3 \mathrm{~mm}$ distal to the compression site at both days 3 and 5 postcompression. Axons with some signs of acute Wallerian degeneration were found in 4 of 11 pmp22 $2^{+/-}$mice $(n=12)$, but not in any of the wild-type mice $(n=12)$. However, only 2 of 12 pmp $22^{+1-}$ mice had severe acute axonal degeneration, as defined by over two-thirds of myelinated nerve fibers showing swelling and collapsed myelin (Fig. 2).

We also evaluated the recovery over multiple time points, using the second compression model in which the sciatic nerve was compressed by a vessel clamp. The compressed nerves were harvested at day 0 (immediately after the compression), and at days $5,7,14,21$, and 30 ( $n=3$ mice for each time point). The reduced CMAP amplitudes induced by the proximal stimulations were completely recovered by day 7 in the wild-type mice $($ distal $\mathrm{CMAP}=6.9 \pm 2.6 \mathrm{mV}$ vs proximal CMAP $=6.4 \pm 2.5$ $\mathrm{mV} ; p>0.05)$, but the recovery was delayed until day 14 in pmp $22^{+1-}$ mice (At day 7, distal CMAP $=2.4 \pm 0.6 \mathrm{mV}$ vs proximal CMAP $=1.9 \pm 0.5 \mathrm{mV}$; At day $14,2.7 \pm 0.5$ vs $2.6 \pm$ $0.4, p>0.05)$.

To determine whether axonal size of mutant or wild-type axons recovered differently following compression we evaluated axons at various time points after inducing $\mathrm{CB}$. The nerves in both $p m p 22^{+/+}$and $p m p 22^{+/-}$mice appeared stretched with smaller diameters, losing their normal undulated, "wave-like" appearance under light microscopy (Fig. 3). This undulated pattern and smaller diameters partially recovered at day 21 , and returned to their normal state by day 30 postcompression in both pmp $22^{+/+}$and $p m p 22^{+/-}$nerves (supplemental Fig. 1, available at www.jneurosci.org as supplemental material). Thus, persistent diffusely smaller diameters of axons could not explain the prolonged recovery from $\mathrm{CB}$ in the mutant animals. We could not determine whether focal constrictions of mutant nerves under tomacula changed following compression. The compressed nerves in all mice were fragile during mechanical manipulations such that any attempt at teasing nerve fibers introduced unacceptable artifact in the focally constricted region.

Morphological examination at each time point demonstrated no or, at most, minimal damage in occasional axons in the compressed nerves of wild-type mice (Fig. 2; supplemental Fig. 1, available at www.jneurosci.org as supplemental material). However, axonal damages were found in all compressed sciatic nerves of $p m p 22^{+/-}$mice, but only limited to a small portion of nerve fibers (supplemental Fig. 1, available at www.jneurosci.org as supplemental material). These degenerating axons were gradually diminishing during the recovery and were rarely detectable by day 30. In addition, on semithin sections, the prevalence of tomacula in the postcompressed nerves appeared similar to that in the nerves from the noncompressed side.

These results suggest that axonal injury was not contributing to $\mathrm{CB}$ in wild-type and played a minor role in Pmp22deficient mice. However, the fact that a small portion of axons in Pmp22-deficient animals had some evidence of axonal damages suggested that Pmp22 insufficiency may make axons more susceptible to injury, which may contribute to the delayed recovery.

\section{Compression does not cause axonal invagination, tomacula} damage, or segmental demyelination in $p m p 22^{+/-}$nerves Nodal invagination has been considered to be the basis of mechanically induced CB in a series of elegant studies by Gilliatt and his colleagues (Ochoa et al., 1971, 1972; Ochoa, 1972; Gilliatt et al., 1974; Rudge et al., 1974). In these studies, either a tourniquet or a nylon cord with an attached weight was applied to baboon's limb, and reversible CB was induced without significant axonal damage. The results suggested that the early phase of $\mathrm{CB}$ was 
caused by displacement of the nodes at the edge of compression, so that the nodes invaginated into the adjacent paranodal area. In addition, paranodal myelin swelling and rupture were also noticed. However, in our osmicated teased nerve fibers, these changes in nodes/paranodes were not found unless we used a much stronger vessel clamp $\left(60 \mathrm{~g} / \mathrm{mm}^{2}\right)$ to induce CB. Otherwise $\mathrm{CB}$ developed in the absence of nodal invagination in our model when milder compression was used.

Tomacula have been considered to be an unstable pathological structure that degenerates as animals age (Adlkofer et al., 1997). We hypothesized that Pmp22deficient myelin may also be unstable and could break down during compression, causing CB. To address this issue, we examined the compressed sciatic nerves from our second compression model, CB induced by clamping exposed sciatic nerve. In this model the compressed nerve segment was wider and much easier to be identified. Osmicated teased nerve fiber studies were performed in three pmp $22^{+/-}$and three $p m p 22^{+/+}$mice. None of the $>100$ randomly selected myelinated nerve fibers from either pmp $22^{+/-}$or $p m p 22^{+/+}$mice showed disruption of myelin. All tomacula examined were intact. Thus, stability of tomacula and myelin did not explain predisposition to CB in our pmp $22^{+/-}$mice.

\section{Molecular architecture and septate junctions of myelinated nerve fibers were normal in $p m p 22^{+/-}$mice}

We next hypothesized that alterations of the molecular organization of $p m p 22^{+/-}$nerves might be responsible for the predisposition to develop $\mathrm{CB}$, since these alterations are known to affect action potential propagation. Along these lines, recent investigations of myelinated axons and their nodes of Ranvier have demonstrated a surprising structural complexity, but very organized architecture, which is thought to be critical for the physiological functions of myelinated nerves (Scherer and Arroyo, 2002; Devaux and Scherer, 2005). To evaluate this architecture in our animals we performed teased nerve fiber immunohistochemistry (IHC) on noncompressed sciatic nerves from both pmp $22^{+/-}$and $p m p 22^{+/+}$mice. Proteins specific to each domain of myelinated nerve fibers, including node, paranode, juxtaparanode, and internode, appeared well expressed and organized identically in mutant and wild-type mice. These included voltage-gated sodium channels $\left(\mathrm{Na}_{\mathrm{v}}\right)$ in the nodes of Ranvier, Caspr, and MAG in the paranodes, $\mathrm{K}_{\mathrm{v}} 1.2$ in juxtaparanode, and myelin basic protein (MBP) in internode (Fig. 3). Therefore, alterations in the localization of these molecules could not explain the predisposition to develop CB in $p m p 22^{+/-}$mice.

We next investigated septate junctions, the structures that connect paranodal loops of myelinating Schwann cell membrane onto the paranodal axolemma. Thus, they seal the inner mesaxon space and separate the juxtaparanodes from nodes. Disrupting septate junctions would allow outward current from juxtaparanodal potassium channels to counteract the inward cur- rent from nodal $\mathrm{Na}_{\mathrm{v}}$, thereby raise the threshold of action potential production and decrease the safety factor for action potential propagation, resulting in CB (Lafontaine et al., 1982; Boyle et al., 2001). However, septate junctions in the paranodes with tomacula appeared normal under EM, in longitudinal ultrathin sections of noncompressed sciatic nerves (Fig. $3 F$, arrowheads).

Although we had demonstrated a normal molecular architecture in noncompressed Pmp22-deficient nerves we recognize that Pmp22 deficiency may predispose changes in the molecular architecture during compression. We dissected sciatic nerves from mutant and wild-type mice after $\mathrm{CB}$ was reached. IHC was performed with antibodies against $\mathrm{K}_{\mathrm{v}} 1.2$ and Caspr. As with noncompressed nerves, no change of expression pattern of these proteins was found in the compressed sciatic nerves from either pmp $22^{+/-}$or $p m p 22^{+/+}$mice. However, axons appeared to have smaller diameters in the compressed nerves (Fig. 3G, H; supplemental Fig. 1, available at www.jneurosci.org as supplemental material).

\section{Concentration of $\mathrm{Na}_{\mathrm{v}}$ was normal in $p m p 22^{+/-}$mice}

Although the localization of $\mathrm{Na}_{\mathrm{v}}$ appeared normal, we recognized that a decrease of $\mathrm{Na}_{\mathrm{v}}$ concentration may also predispose $\mathrm{CB}$ by reducing the safety factor for action potential production (Kearney et al., 2002). We therefore performed a $\left[{ }^{3} \mathrm{H}\right]-\mathrm{STX}$ binding assay to determine $\mathrm{Na}_{\mathrm{v}}$ concentration in noncompressed peripheral nerves. Due to the overall low concentration of $\mathrm{Na}_{\mathrm{v}}$ in the peripheral nerves (Lombet et al., 1985), we had to collect nerves from 11 to 15 mice of each genotype and pooled mem- 


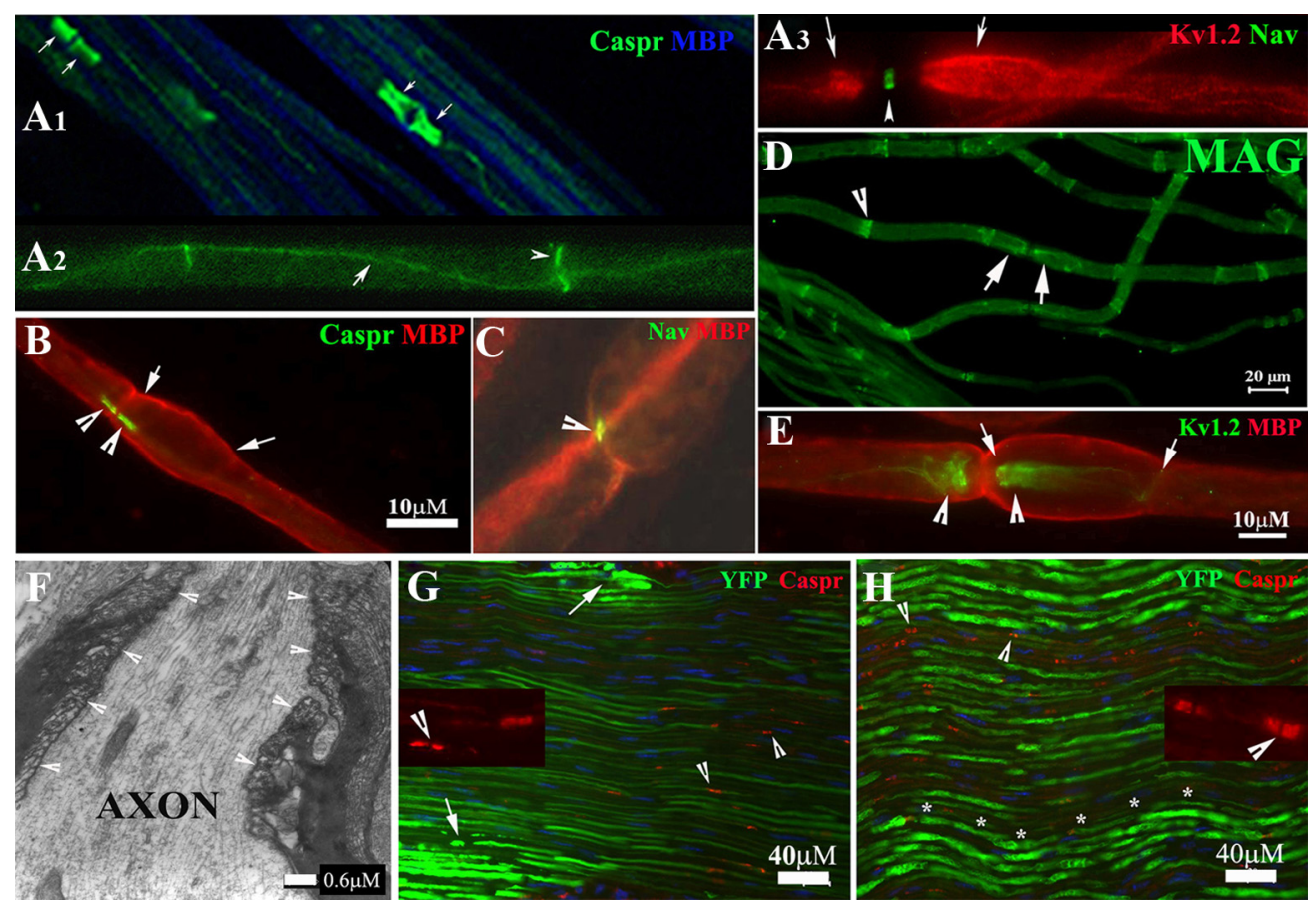

Figure 3. Molecular architecture and septate junctions in naive and compressed nerves. $A_{1}-A_{3}$, Wild-type mice at $2-3$ months old were perfused. Noncompressed sciatic nerves were dissected and teased into individual nerve fibers. Slides were stained with antibodies against MBP (blue) and Caspr (green). The former revealed internodal myelin (blue in $\boldsymbol{A}_{7}$ ). Caspr stained paranodes (arrows) that flanked the node of Ranvier. Caspr was also expressed at the Schmidt-Lanterman incisures (arrowhead in $A_{2}$ ) and along the inner mesaxon as it spirals around the axon (arrow in $A_{3}$ ). Voltage-gated potassium channels $\left(\mathrm{K}_{\mathrm{v}} 1.2\right.$; red in $\boldsymbol{A}_{3}$ ) were found in the juxtaparanodes (arrows in $\boldsymbol{A}_{3}$ ). Nav were concentrated in the node of Ranvier (arrowhead in $A_{3}$ ) and appeared as a narrow band. $\boldsymbol{B}-\boldsymbol{E}$, From noncompressed $p m p 22^{+-}$nerves. $\mathrm{Na}_{\mathrm{v}}, \mathrm{K}_{\mathrm{v}} 1.2$, Caspr, and MBP were all localized in their proper regions. In addition, MAG was also correctly localized in the paranodes (D, arrows) and incisures (arrowhead in $\boldsymbol{D}$ ) similar to what was observed in the wild-type myelinated nerve fibers. Tomacula were found mainly in the paranodal regions $(\boldsymbol{B}, \boldsymbol{E})$ and almost always extended beyond the paranodes and into juxtaparanodes and internodes (between arrows in $\boldsymbol{B}$ and $\boldsymbol{E}$ ). $\boldsymbol{F}$, EM was performed on the longitudinal section of a noncompressed $p m p 22^{+/-}$sciatic nerve. Normal paranodal septate junctions (arrowhead array) were observed in the region with tomacula. $\mathbf{G}, \boldsymbol{H}$, Compressed sciatic nerves from the second compression model (surgically exposed and clamped sciatic nerve) $(\boldsymbol{G})$ and noncompressed sciatic nerves $(\boldsymbol{H})$ were sectioned into $10 \mu \mathrm{m}$ thickness and stained with antibodies against Caspr. The localization of Caspr in the paranodes (arrowheads in $\mathbf{G}$ and insets and also in supplemental Fig. 1, available at www.jneurosci.org as supplemental material) was normal in compressed nerves. So was that of $K_{v} 1.2$. However, axons revealed by YFP had smaller diameters and appeared stretched (G). Supporting this notion, we observed the typical undulating "wave" appearance of axons in noncompressed nerve (asterisk array in $\boldsymbol{H}$ ). However, these waves disappeared in the compressed nerve $(\boldsymbol{G})$, suggesting that the compressed nerve was physically stretched during the compression. Notice that the intensity of axonal YFP was much weaker in the compressed nerves. This change has been very helpful for precisely defining the region of compression (please see supplemental Fig. 1, available at www.jneurosci.org as supplemental material, for details). Within the compressed region, there were small islands of axons with strong intensity (arrows in $\mathbf{G}$ and in supplemental Fig. 1A, available at www.jneurosci.org as supplemental material), which likely were spared from compression forces. Insets, Caspr localization in paranodes was visualized under high power.

brane proteins together for each experiment. Three experiments were done. The mean of $\mathrm{Na}_{\mathrm{v}}$ concentration was $537 \pm 153 \mathrm{fmol} / \mathrm{mg}$ in pmp $22^{+/+}$mice and $603 \pm 132 \mathrm{fmol} / \mathrm{mg}$ in $p m p 22^{+/-}$mice; these differences were not significant $(p>0.05)$. Thus the total quantity of $\mathrm{Na}_{\mathrm{v}}$ could not explain the predisposition to $\mathrm{CB}$ in the mutant mice.

\section{Axons encased by tomacula were constricted, a potential mechanism for shortened induction-time of CB in PMP22 insufficiency}

Because there was no evidence of any myelin or molecular architecture change to explain the predisposition to $\mathrm{CB}$ in the preceding experiments, we next examined potential differences of axons between mutant and wild-type animals. We cross-bred $p m p 22^{+/-}$mice with YFPtg $^{+/+}$mice. Axons in all offspring were labeled by YFP, so that axonal structures can be visualized with great clarity.

We found focal constrictions in the axonal segments enclosed by tomacula in noncompressed $p m p 22^{+1-}$ myelinated nerve fibers (Fig. $4 B, C, F$ ). We defined tomacula as a focal enlargement of myelin by $1 / 3$ of internodal diameter of the myelinated fiber. Axonal constriction was defined as segments with diameters reduced by $1 / 3$ of the internodal axonal diameter. Axonal diameters decrease naturally in the nodal and paranodal regions of a normal myelinated nerve fiber (Fig. 4A). Tomacula caused the axonal constriction to extend well beyond the paranodes. In some cases, tomacula caused a greater reduction in axonal caliber than seen at nodes and paranodes (Fig. $4 B, C$ ). To quantify this observation we randomly selected 20 paranodes with tomacula/axonal constrictions from 5 pmp22 $22^{+/-}$mice and 20 paranodes without tomacula from five wild-type mice. Lengths of constricted axonal segments were measured in each paranode. The mean length of the constricted segments was $19.4 \pm 4.9 \mu \mathrm{m}$ for paranodes with tomacula/constrictions and $4.2 \pm 0.2 \mu \mathrm{m}$ for paranodes without tomacula ( $p<0.0001)$ (Fig. $4 G)$.

The prevalence of tomacula and axonal constrictions was manually assessed in 50 randomly selected nodes from each 6-month-old $p m p 22^{+/-}$or $p m p 22^{+/+}$mouse $(n=5$ mice for each genotype) (Table 3 ). For most selected fibers, only one node in each myelinated fiber was evaluated. Regions with Schwann cell nucleus were avoided since there is a natural reduction of axonal diameter around the nucleus. Nearly half of the myelinated nerve fibers $(48.4 \pm 12.3 \%)$ contained tomacula in 6-month-old $p m p 22^{+/-}$mice. Tomacula were mainly found in the paranodal regions of large myelinated fibers $(>5 \mu \mathrm{m})$ although they occasionally occurred in the internodes. Because 
only one node was examined in each selected myelinated fiber, the actual prevalence of tomacula may even have been higher. Focal constrictions were developed by $15.9 \pm 4.8 \%$ of all evaluated axons. These constrictions were always within tomacula. Interestingly, a few axons in the tomacula $(4.0 \pm 2.5 \%)$ were enlarged by at least $1 / 3$ of internodal axonal diameter (Fig. 4D). These enlargements presumably reflected axons that extended into myelin folds (Fig. $4 E$; supplemental Fig. 2B, $C$, available at www. jneurosci.org as supplemental material). Other axonal deformities within tomacula were also noticed (supplemental Fig. 2, available at www.jneurosci.org as supplemental material). Overall, these pathological changes (tomacula, axonal constriction, and enlargements) were present but slightly less ( $12 \%$ of evaluated axons) in 3-monthold pmp $22^{+/-}$mice (Table 3 ).

\section{Discussion}

Our results demonstrate that mechanically induced CB occurs more rapidly and lasts longer in Pmp22-deficient nerves than in wild-type nerves. This finding was replicated in three sets of experiments by two different compression techniques. These findings confirm a hypothesis that has long been held concerning HNPP; namely that $50 \%$ of the normal PMP22 levels are inadequate to fully protect myelinated nerve fibers from compressive injury. Therefore one biological function of PMP22 must be protection from nerve injury.

The ease to develop CB cannot be explained simply because of reduced CMAP amplitudes in the mutant nerves (Fig. $1 E$ ). CB was determined by using P/D ratio, not the absolute value of CMAP amplitudes. Moreover, when induction time of CB was compared between two groups of mice with low and high CMAP, no significant difference was found (supplemental Table 1, available at www.jneurosci.org as supplemental material). Therefore, we believe that $\mathrm{CB}$ is directly related to Pmp22 deficiency.

We have identified focal axonal constrictions within tomacula as a novel potential cause of increased susceptibility to $C B$ in Pmp22-deficient mice. Axonal constrictions were identified only within segments enclosed by tomacula and were triple/quadruple the length of constricted segments normally found in nodes/ paranodes. Reduced axonal diameter rapidly raises axial resistance to action potential propagation since axial electric resistance of axons is inversely proportion to the square of axonal diameter (Hartline and Colman, 2007). Once the resistance increases to a critical level, CB occurs. We hypothesize that these multiple constricted axons within tomacula predispose the axons to $\mathrm{CB}$. Furthermore, when the nerve is compressed, this causes even further stretching and thinning of axons (Fig. 3G; supplemental Fig. $1 A$, available at www.jneurosci.org as supplemental material). We postulate that this is the basis for the predisposition to $\mathrm{CB}$ observed in HNPP. Supporting our findings, reduced ax-
Table 3. Prevalence of tomacula and axonal constrictions in pmp22 ${ }^{+/-}$mice

\begin{tabular}{llll}
\hline Age & Tomacula (\%) & Axonal constrictions (\%) & $\begin{array}{l}\text { Axonal } \\
\text { enlargement (\%) }\end{array}$ \\
\hline 3 months $(n=6$ mice) & $45.3 \pm 0.4 \%^{a}$ & $26.7 \pm 7.5^{b}$ or $12.1 \pm 3.4^{a}$ & $5.3 \pm 3.7^{b}$ \\
6 months $(n=5$ mice) & $48.4 \pm 12.3 \%^{a}$ & $32.0 \pm 9.9^{b}$ or $15.9 \pm 4.8^{a}$ & $4.0 \pm 2.5^{b}$ \\
\hline${ }^{a}$ Percentage of all counted myelinated nerve fibers. & &
\end{tabular}

${ }^{a}$ Percentage of all counted myelinated nerve fibers.

${ }^{b}$ Percentage of myelinated fibers with tomacula.

onal diameters within tomacula have been identified in EM sections of sural nerve biopsies from patients with HNPP, although these findings were not quantified (Madrid and Bradley, 1975).

A potential concern for our hypothesis is whether the quantity of axonal constrictions we observed would be sufficient to predispose CB. Internodal length in mouse myelinated nerve fibers is $561 \pm 136 \mu \mathrm{m}$ (Perrot et al., 2007). A vessel clamp with a width of $1.5 \mathrm{~mm}(1500 \mu \mathrm{m})$ covers $2-3$ nodes. When one node per myelinated nerve fiber was examined in 3-month-old pmp $22^{+l-}$ mice, $12 \%$ of fibers showed focal axonal constrictions (Table 3 ). Thus, up to $36 \%$ of fibers, and most of the largest diameter fibers, have constrictions in nerve segments that are covered by the vessel clamp, which also means that $36 \%$ of fibers under the compression of a $1.5-\mathrm{mm}$-width clamp are predisposed to CB. More importantly, it is the large myelinated fibers that are responsible 
for the major portion of CMAP, which is reduced in CB. For instance, with stronger and longer compression to achieve 60$100 \%$ CB in previous studies, pathological changes were still observed mainly in large myelinated fibers (Ochoa et al., 1972), and small fibers were spared (Ochoa et al., 1972; Fowler and Ochoa, 1975). In fact, early occurrence of slowing across the compression site in our experiments and previous compression studies (Rudge et al., 1974) also indicated that the large myelinated fibers were preferentially affected since conduction velocity measures the conduction of largest myelinated fibers (Gasser HS and Grundfest $H, 1939$ ). Finally, other pathological alterations in $p m p 22^{+/-}$ nerves, such as the enlargements of paranodal axons in the tomacula (Fig. $4 D, E$ ), may also contribute to the rapid induction of CB. These convoluted axolemma may increase the total areas of paranodal axolemma and raise the capacitance, leading to a reduction of safety factor for action potential propagation (Joyner et al., 1980).

Our data do not claim that axonal constrictions in tomacula are the only cause for the $\mathrm{CB}$, and the causal role of axonal deformities in the $\mathrm{CB}$ remains to be established. For example, wildtype mice also developed a decline in CMAP amplitudes after 5 min of compression and $\mathrm{CB}$ within $30 \mathrm{~min}$. It simply occurs more rapidly in the mutant mice for a given level of compression. We do not know what other factors cause CB in wild-type animals. However the classical studies of Gilliatt and colleagues implicating nodal invagination cannot explain CB in our models since even wild-type mice did not demonstrate nodal invagination associated with their block unless stronger compression was applied.

How tomacula and axonal constrictions are formed remains a mystery. Tomacula are not unique to PMP22 insufficiency. They have been found in other neuropathies and animal models, including anti-MAG neuropathy, CMT1B, chronic inflammatory demyelinating neuropathy, Tangier's disease, as well as several animal models of peripheral nerve disorders (Sander et al., 2000; Cai et al., 2002, 2006). It has been hypothesized that tomacula result from excessive myelin folding collapsed on constricted axons in MAG knock-out mice (Yin et al., 1998). However, these findings have been challenged after focal hypermyelination was found in $\mathrm{mag}^{-1-}$ mice at young age when axonal diameters were still normal (Cai et al., 2002). Thus, these findings suggest that tomacula are formed first and subsequently induce focal axonal constrictions by unknown mechanisms in MAG deficiency, such as abnormal Schwann cell-axon interaction. Whether this is also the case in PMP22 deficiency remains to be clarified. Whether there is an abnormal signaling through MAG in PMP22 deficiency is also unknown. Nevertheless, our data suggest that normal dosage of PMP22 is required to prevent formation of axonal constriction, which may be the mechanism of the protection it provides from nerve injury.

Susceptibility to mechanically induced CB was not restricted to PMP22-deficient nerves. It was also found in our $\mathrm{mag}^{-1-}$ mice in the absence of tomacula. A recent study suggests that MAG deficiency destabilizes axons through a signaling pathway independent of Nogo protein complex.(Nguyen et al., 2009). Thus, results from both $p m p 22^{+/-}$and $\mathrm{mag}^{-1-}$ nerves suggest that this susceptibility to $\mathrm{CB}$ is likely due to effects on the axon, rather than from myelin instability alone since this vulnerability was not found in Mpz-deficient nerves.

Finally, we found axonal damage in a small portion of pmp $22^{+/-}$nerves that were compressed. These alterations disrupted axons between the proximal and distal stimulation sites and produce what might initially appear as CB (pseudo-CB).
However, evidence of Wallerian degeneration was not seen in the vast majority of axons and is not a viable explanation for CB for our results. We do not know what other factors contributed to the delayed recovery from CB in the mutant mice. Our results did not show a delayed recovery from nerve stretching or an increased number of tomacula in the postcompressed nerve fibers. It is possible that a delayed recovery of focally constricted axons, under tomacula, is a contributing factor.

Although acute axonal damage occurred only rarely in pmp $22^{+/-}$mice, it does have important clinical significance in humans. In one case report, a 20-year-old woman with HNPP developed massive axonal degeneration in her arms after strenuous physical activities, including running with a $34 \mathrm{~kg}$ backpack and performing 150 push-ups a day (Horowitz et al., 2004). We also identified a similar case. This 48-year-old man with HNPP developed arm weakness after heavy weight lifting. Needle EMG showed significant denervation in his arms, demonstrating that he had undergone acute Wallerian degeneration. Together, mechanical challenges during long or extraneous physical activities may be safe for healthy people, but could be dangerous to patients with HNPP.

\section{References}

Adlkofer K, Martini R, Aguzzi A, Zielasek J, Toyka KV, Suter U (1995) Hypermyelination and demyelinating peripheral neuropathy in Pmp22deficient mice. Nat Genet 11:274-280.

Adlkofer K, Frei R, Neuberg DH, Zielasek J, Toyka KV, Suter U (1997) Heterozygous peripheral myelin protein 22-deficient mice are affected by a progressive demyelinating tomaculous neuropathy. J Neurosci 17:4662-4671.

Amici SA, Dunn WA Jr, Notterpek L (2007) Developmental abnormalities in the nerves of peripheral myelin protein 22-deficient mice. J Neurosci Res 85:238-249.

Bai Y, Ianokova E, Pu Q, Ghandour K, Levinson R, Martin JJ, Ceuterick-de Groote C, Mazanec R, Seeman P, Shy ME, Li J (2006) R69C mutation in P0 gene alters myelination and ion channel subtypes. Arch Neurol 63:1787-1794.

Bishop DL, Misgeld T, Walsh MK, Gan WB, Lichtman JW (2004) Axon branch removal at developing synapses by axosome shedding. Neuron 44:651-661.

Boyle ME, Berglund EO, Murai KK, Weber L, Peles E, Ranscht B (2001) Contactin orchestrates assembly of the septate-like junctions at the paranode in myelinated peripheral nerve. Neuron 30:385-397.

Cai Z, Sutton-Smith P, Swift J, Cash K, Finnie J, Turnley A, Thompson PD, Blumbergs PC (2002) Tomacula in MAG-deficient mice. J Peripher Nerv Syst 7:181-189.

Cai Z, Blumbergs PC, Cash K, Rice PJ, Manavis J, Swift J, Ghabriel MN, Thompson PD (2006) Paranodal pathology in Tangier disease with remitting-relapsing multifocal neuropathy. J Clin Neurosci 13:492-497.

Catterall WA, Morrow CS, Hartshorne RP (1979) Neurotoxin binding to receptor sites associated with voltage-sensitive sodium channels in intact, lysed, and detergent-solubilized brain membranes. J Biol Chem 254: 11379-11387.

Chance PF, Alderson MK, Leppig KA, Lensch MW, Matsunami N, Smith B, Swanson PD, Odelberg SJ, Disteche CM, Bird TD (1993) DNA deletion associated with hereditary neuropathy with liability to pressure palsies. Cell 72:143-151.

Chen C, Bharucha V, Chen Y, Westenbroek RE, Brown A, Malhotra JD, Jones D, Avery C, Gillespie PJ 3rd, Kazen-Gillespie KA, Kazarinova-Noyes K, Shrager P, Saunders TL, Macdonald RL, Ransom BR, Scheuer T, Catterall WA, Isom LL (2002) Reduced sodium channel density, altered voltage dependence of inactivation, and increased susceptibility to seizures in mice lacking sodium channel beta 2-subunits. Proc Natl Acad Sci U S A 99:17072-17077.

Cornblath DR, Sumner AJ, Daube J, Gilliat RW, Brown WF, Parry GJ, Albers JW, Miller RG, Petajan J (1991) Conduction block in clinical practice. Muscle Nerve 14:869-871; discussion 867-868.

Devaux JJ, Scherer SS (2005) Altered ion channels in an animal model of Charcot-Marie-Tooth disease type IA. J Neurosci 25:1470-1480. 
Dyck PJ, Lambert EH (1968) Lower motor and primary sensory neuron diseases with peroneal muscular atrophy. I. Neurologic, genetic, and electrophysiologic findings in hereditary polyneuropathies. Arch Neurol 18:603-618.

Einheber S, Zanazzi G, Ching W, Scherer S, Milner TA, Peles E, Salzer JL (1997) The axonal membrane protein Caspr, a homologue of neurexin IV, is a component of the septate-like paranodal junctions that assemble during myelination. J Cell Biol 139:1495-1506.

Fowler TJ, Ochoa J (1975) Unmyelinated fibers in normal and compressed peripheral nerves of the baboon: a quantitative electron microscopic study. Neuropathol Appl Neurobiol 1:247-265.

Gasser HS, Grundfest H (1939) Axon diameter in relation to the spike dimentions and conduction velocity in mammalian A fibers. Am J Physiol 127:393-414.

Gilliatt RW, McDonald WI, Rudge P (1974) Proceeding: the site of conduction block in peripheral nerves compressed by a pneumatic tourniquet. J Physiol 238:31P-32P.

Hartline DK, Colman DR (2007) Rapid conduction and the evolution of giant axons and myelinated fibers. Curr Biol 17:R29-R35.

Horowitz SH, Spollen LE, Yu W (2004) Hereditary neuropathy with liability to pressure palsy: fulminant development with axonal loss during military training. J Neurol Neurosurg Psychiatry 75:1629-1631.

Isom LL, Scheuer T, Brownstein AB, Ragsdale DS, Murphy BJ, Catterall WA (1995) Functional co-expression of the beta 1 and type IIA alpha subunits of sodium channels in a mammalian cell line. J Biol Chem 270: 3306-3312.

Jetten AM, Suter U (2000) The peripheral myelin protein 22 and epithelial membrane protein family. Prog Nucleic Acid Res Mol Biol 64:97-129.

Joyner RW, Westerfield M, Moore JW (1980) Effects of cellular geometry on current flow during a propagated action potential. Biophys J 31:183-194.

Kaji R (2003) Physiology of conduction block in multifocal motor neuropathy and other demyelinating neuropathies. Muscle Nerve 27:285-296.

Kearney JA, Buchner DA, De Haan G, Adamska M, Levin SI, Furay AR, Albin RL, Jones JM, Montal M, Stevens MJ, Sprunger LK, Meisler MH (2002) Molecular and pathological effects of a modifier gene on deficiency of the sodium channel Scn8a (Na(v)1.6). Hum Mol Genet 11:2765-2775.

Lafontaine S, Rasminsky M, Saida T, Sumner AJ (1982) Conduction block in rat myelinated fibres following acute exposure to anti-galactocerebroside serum. J Physiol 323:287-306.

Lewis RA, Sumner AJ, Shy ME (2000) Electrophysiological features of inherited demyelinating neuropathies: a reappraisal in the era of molecular diagnosis. Muscle Nerve 23:1472-1487.

Li J, Krajewski K, Shy ME, Lewis RA (2002) Hereditary neuropathy with liability to pressure palsy: the electrophysiology fits the name. Neurology 58:1769-1773.

Li J, Krajewski K, Lewis RA, Shy ME (2004) Loss-of-function phenotype of hereditary neuropathy with liability to pressure palsies. Muscle Nerve 29:205-210.

Li J, Bai Y, Ghandour K, Qin P, Grandis M, Trostinskaia A, Ianakova E, Wu X, Schenone A, Vallat JM, Kupsky WJ, Hatfield J, Shy ME (2005) Skin biopsies in myelin-related neuropathies: bringing molecular pathology to the bedside. Brain 128:1168-1177.

Li J, Ghandour K, Radovanovic D, Radovanovic D, Shy RR, Krajewski KM, Shy ME, Nicholson GA (2007) Stoichiometric alteration of PMP22 protein determines the phenotype of HNPP. Arch Neurol 64:974-978.

Lombet A, Laduron P, Mourre C, Jacomet Y, Lazdunski M (1985) Axonal transport of the voltage-dependent $\mathrm{Na}+$ channel protein identified by its tetrodotoxin binding site in rat sciatic nerves. Brain Res 345:153-158.

Madrid R, Bradley G (1975) The pathology of neuropathies with focal thickening of the myelin sheath (tomaculous neuropathy): studies on the formation of the abnormal myelin sheath. J Neurol Sci 25:415-448.
Marazzi R, Pareyson D, Scaioli V, Corbo M, Boiardi A, Chiodelli G, Sghirlanzoni A (1988) Recurrent familial neuropathy due to liability to pressure palsies. Ital J Neurol Sci 9:355-363.

Martini R, Mohajeri MH, Kasper S, Giese KP, Schachner M (1995) Mice doubly deficient in the genes for $\mathrm{P} 0$ and myelin basic protein show that both proteins contribute to the formation of the major dense line in peripheral nerve myelin. J Neurosci 15:4488-4495.

McKinnon D (1989) Isolation of a cDNA clone coding for a putative second potassium channel indicate the existence of a gene family. J Biol Chem 264:8230-8236.

Nguyen T, Mehta NR, Conant K, Kim KJ, Jones M, Calabresi PA, Melli G, Hoke A, Schnaar RL, Ming GL, Song H, Keswani SC, Griffin JW (2009) Axonal protective effects of the myelin-associated glycoprotein. J Neurosci 29:630-637.

Ochoa J (1972) Ultrathin longitudinal sections of single myelinated fibres for electron microscopy. J Neurol Sci 17:103-106.

Ochoa J, Danta G, Fowler TJ, Gilliatt RW (1971) Nature of the nerve lesion caused by a pneumatic tourniquet. Nature 233:265-266.

Ochoa J, Fowler TJ, Gilliatt RW (1972) Anatomical changes in peripheral nerves compressed by a pneumatic tourniquet. J Anat 113:433-455.

Perrot R, Lonchampt P, Peterson AC, Eyer J (2007) Axonal neurofilaments control multiple fiber properties but do not influence structure or spacing of nodes of Ranvier. J Neurosci 27:9573-9584.

Robertson AM, Perea J, McGuigan A, King RH, Muddle JR, Gabreëls-Festen AA, Thomas PK, Huxley C (2002) Comparison of a new pmp22 transgenic mouse line with other mouse models and human patients with CMT1A. J Anat 200:377-390.

Rudge P, Ochoa J, Gilliatt RW (1974) Acute peripheral nerve compression in the baboon. J Neurol Sci 23:403-420.

Sancho S, Young P, Suter U (2001) Regulation of Schwann cell proliferation and apoptosis in PMP22-deficient mice and mouse models of CharcotMarie-Tooth disease type 1A. Brain 124:2177-2187.

Sander S, Ouvrier RA, McLeod JG, Nicholson GA, Pollard JD (2000) Clinical syndromes associated with tomacula or myelin swellings in sural nerve biopsies. J Neurol Neurosurg Psychiatry 68:483-488.

Scherer SS, Arroyo EJ (2002) Recent progress on the molecular organization of myelinated axons. J Peripher Nerv Syst 7:1-12.

Shy ME, Arroyo E, Sladky J, Menichella D, Jiang H, Xu W, Kamholz J, Scherer SS (1997) Heterozygous P0 knock-out mice develop a peripheral neuropathy that resembles chronic inflammatory demyelinating polyneuropathy (CIDP). J Neuropathol Exp Neurol 56:811-821.

Shy ME, Balsamo J, Lilien J, Kamholz J (2001) A molecular basis for hereditary motor and sensory neuropathy disorders. Curr Neurol Neurosci Rep $1: 77-88$.

Ulzheimer JC, Peles E, Levinson SR, Martini E (2004) Altered expression of ion channel isoforms at the node of Ranvier in P0-deficient myelin mutants. Mol Cell Neurosci 25:83-94.

Yamamoto Y, Mizuno R, Nishimura T, Ogawa Y, Yoshikawa H, Fujimura H, Adachi E, Kishimoto T, Yanagihara T, Sakoda S (1994) Cloning and expression of myelin-associated oligodendrocytic basic protein. A novel basic protein constituting the central nervous system myelin. J Biol Chem 269:31725-31730.

Yin X, Crawford TO, Griffin JW, Tu P, Lee VM, Li C, Roder J, Trapp BD (1998) Myelin-associated glycoprotein is a myelin signal that modulates the caliber of myelinated axons. J Neurosci 18:1953-1962.

Yoshikawa H, Dyck PJ (1991) Uncompacted inner myelin lamellae in inherited tendency to pressure palsy. J Neuropathol Exp Neurol 50:649-657.

Zhang X, Chow CY, Sahenk Z, Shy ME, Meisler MH, Li J (2008) Mutation of FIG4 causes a rapidly progressive, asymmetric neuronal degeneration. Brain 131:1990-2001. 